\title{
COMPARATIVE PERFORMANCE OF GEOPOLYMER CONCRETE EXPOSED TO ACIDIC ENVIRONMENT
}

\author{
Srinivas K S , M T Prathap Kumar $^{2}$, W P Prema Kumar ${ }^{3}$ \\ ${ }^{l}$ PG student, Department of Civil Engineering, Reva Institute of Technology and Management, Bengaluru, Karnataka, \\ India \\ ${ }^{2}$ Senior Professor and PG Coordinator, Department of Civil Engineering, Reva Institute of Technology and \\ Management, Bengaluru, Karnataka, India \\ ${ }^{3}$ Senior Professor and R\&D Dean, Department of Civil Engineering, Reva Institute of Technology and Management, \\ Bengaluru, Karnataka, India
}

\begin{abstract}
Geopolymer concrete is emerging as an alternate green material in the construction industry. It is produced from the reaction of silica and alumina rich materials with alkaline liquid. Reviews of literatures have indicated that geopolymer concrete (GPC) have better acid resistant and hence can be used in many applications, including its use as sewer pipes. However, very few studies have comparatively assessed performance of GPC as acid resistant material when compared with conventional concrete. This paper presents the experimental investigation done on compressive strength of geopolymer concrete subjected to acidic conditions and compared with conventional concrete performance under the same acidic conditions.. The grades chosen for the investigation is $M-40 \& G 40$, the mixes were designed for molarity of $8 M, 12 M$ and 16M.Initially Geopolymer concrete and Conventional concrete cubes were immersed in $5 \%$ acid solutions consisting of $\mathrm{H}_{2} \mathrm{SO}_{4}$ and $\mathrm{MgSO}$,for a period of 7, 14 and 28 days. The mass loss, compressive strength reductions were determined..The results confirmed that Geopolymer concrete is highly resistant to acid in terms of low mass loss and compressive strength loss when compared to conventional concrete
\end{abstract}

Keywords: alkaline liquids, flyash, compressive strength, mass loss

\section{INTRODUCTION}

Geopolymer concrete is a concrete consisting of materials like fly ash or ground granulated blast furnace sag (GGBS) instead of cement, Aggregate and Alkaline liquids (Sodium hydroxide and Sodium silicate or Potassium hydroxide and Potassium silicate solutions) instead of water. The term Geopolymer is a three-dimensional alumino-silicates material, which is a binder produced from the reaction of a source material consisting of high silica ( $\mathrm{Si}$ ) and aluminum (Al) with a concentrated alkaline solution. The production of Portland cement worldwide is increasing 9\% annually, causing high amount of carbon dioxide gas being released to the atmosphere. In India about 2,069,738 thousands of metric tons of $\mathrm{CO}_{2}$ is emitted in the year 2010. On the other side the demand for concrete is increasing day by day for its ease of preparing and fabricating in all sorts of convenient shapes. So to overcome this problem, the concrete to be used should be eco friendly. Geopolymer concrete is a 'new' material that does not need the presence of Portland cement as a binder. Many studies are carried out for the compressive strength and durability properties of conventional concrete but a few studies are carried out on Geopolymer concrete regarding compressive strength and durability factors indicating better performance than Conventional concrete under acidic exposure [1-4]. Studies carried out on development of strength for various grades of geopolymer concrete with varying molarity of alkaline liquids. Effect of molarity of alkaline liquids on
Compressive strength of GPC was tested at the age of 7 and 28 days. GPC mix formulations with compressive strength ranging from 15 to $52 \mathrm{MPa}$ have been developed [5-6]. Durability studies on GPC and conventional concrete were studied by immersing under $10 \%$ sulphuric acid and $10 \%$ magnesium sulphate solutions separately and, periodic monitoring of surface deterioration and depth of dealkalization showed an excellent resistance to acid and sulphate attack by GPC specimens when compared to conventional concrete [7]. However, most of these studies have assessed performance of GPC in terms of compressive strength alone. Comparative performance assessment with conventional concrete is very few in literature.

The present study considers Fly ash and GGBS utilization in production of Geopolymer concrete since it can accommodate a major portion of the ash and slag produced. The alkaline liquids are usually Sodium $(\mathrm{Na})$ or Potassium $(\mathrm{K})$ based. High alkaline liquids are used to induce the silica and aluminum atoms in the source materials to dissolve and form the geopolymeric binder. Mix design for G40 and M40 for GPC and conventional concrete respectively were done and a comparative assessment of mass loss and loss in compressive strength were determined by immersing the standard sized cubes in $5 \%$ acidic solutions consisting of $\mathrm{H}_{2} \mathrm{SO}_{4}$ and $\mathrm{MgSO}$, for a period of 7, 14 and 28 days. 


\section{MATERIALS USED}

\subsection{Flyash and GGBS}

Class F Flyash was used which was obtained from RDC Concrete Plant Yelahanka, Bangalore. Flyash is finely grained residue resulting from the combustion of ground or powdered coal. Mean particle size is about 0.1 to $0.2 \mu \mathrm{m}$ and finer than cement. The specific gravity, fineness modulus of Flyash are 2.82, 1.375, respectively.

Ground granulated blast furnace slag that was obtained from Surya Concrete Plant Yelahanka, Bangalore, having fineness modulus of 0.16 was used in the work. The specific gravity of GGBS is 2.90 .

\subsection{Alkaline Liquid}

The alkaline liquid is prepared by mixing sodium hydroxide pellets mixed with water in different concentration and sodium silicate solution together at least 24 hours prior to use for thorough mixing and reaction. Ratio of these solutions is 2.5 . The solids are dissolved in water to prepare the $\mathrm{NaOH}$ solution of required concentration of $8 \mathrm{M}, 12 \mathrm{M}$ and $16 \mathrm{M}$. After the pellets dissolved fully in the water, then sodium silicate was added to make alkaline solution.

\subsection{Fine Aggregate}

The fine aggregate used is natural river sand conforming to grading zone-II of table 4 of IS: 383-1970. The specific gravity and fineness of the fine aggregates are 2.63 and $2.4 \%$ respectively.

\subsection{Coarse Aggregate}

The crushed coarse aggregate of maximum $20 \mathrm{~mm}$ down size is used in the present study. The specific gravity of the coarse aggregate was 2.60 .

\subsection{Cement}

Ordinary Portland Cement confirming to grade 53 with specific gravity of 3.15 was used.

\subsection{Acid}

Concentrated $\mathrm{H}_{2} \mathrm{SO}_{4}$ and $\mathrm{MgSO}_{4}$ were mixed in water to each of 5\% concentration that enables the GPC and conventional concrete cubes to be immersed in acidic environment.

\section{MIX-DESIGN FOR GPC (G40 GRADE)}

The mix design proposed by Madheswaran et al (2013) was used for design GPC of grade G40 [5].

Take a Density of concrete $=2400 \mathrm{~kg} / \mathrm{m}^{3}$

Take mass of combined aggregate $=75 \%$ to $80 \%$

$=0.77 * 2400$

$=1848 \mathrm{~kg} / \mathrm{m}^{3}$
Take fine aggregate to total aggregate ratio $=0.45$ (from least void ratio graph)

Weight of fine aggregate $=0.45 * 1848=831.6 \mathrm{~kg} / \mathrm{m}^{3}$

Weight of coarse aggregate $=1848-831.6$

$=1016.4 \mathrm{~kg} / \mathrm{m}^{3}$

Take fluid/ binder ratio $=0.6$

Weight of binder + solution $=2400-1848$

$=552 \mathrm{~kg} / \mathrm{m}^{3}$

Weight of binder only $=(551 * 1) /(1+0.6)$

$=345 \mathrm{~kg} / \mathrm{m}^{3}$

Weight of fluid $=552-345$

$=207 \mathrm{~kg} / \mathrm{m}^{3}$

The ratio of $\mathrm{NaOH}$ and $\mathrm{Na}_{2} \mathrm{Sio}_{3}$ is $1: 2.5$

So, $\mathrm{NaOH}=(207) *(1) /(1+2.5)$

$$
=59.14 \mathrm{~kg} / \mathrm{m}^{3}
$$

$\mathrm{Na}_{2} \mathrm{SiO}_{3}=59.14 * 2.5=147.85 \mathrm{~kg} / \mathrm{m}^{3}$

The total quantities of materials for $1 \mathbf{~ m}^{3}$

Mass of binder $=345 \mathrm{~kg} / \mathrm{m}^{3}$

Mass of fluid $=\mathrm{NaOH}=59.14 \mathrm{~kg} / \mathrm{m}^{3}$

$\mathrm{Na}_{2} \mathrm{SiO}_{3}=147.85 \mathrm{~kg} / \mathrm{m}^{3}$

Mass of fine aggregate $=831.6 \mathrm{~kg} / \mathrm{m}^{3}$

Mass of coarse aggregate $=1016.4 \mathrm{~kg} / \mathrm{m}^{3}$

\section{For cube size $(150 * 150 * 150) \mathrm{mm}$}

Volume of cube size $(150 * 150 * 150) \mathrm{mm}=0.003375 \mathrm{~m}^{3}$

Mass of binder $=345 * 0.003375$

$=1.164 \mathrm{~kg} / \mathrm{m}^{3}$

Mass of fluid $=\mathrm{NaOH}=59.14 * 0.003375=0.200 \mathrm{~kg}$

$\mathrm{Na}_{2} \mathrm{SiO}_{3}=147.85 * 0.003375=0.500 \mathrm{~kg}$

Mass of fine aggregate $=831.6 * 0.003375=2.806 \mathrm{~kg}$

Mass of coarse aggregate $=1016.4 * 0.003375=3.430 \mathrm{~kg}$

Extra water added $=20 \%$ of binder taken

\section{MIX DESIGN for Conventional Concrete (M40}

\section{GRADE)}

Mix design confirming to IS: 10262-2009 was done and the following were the materials obtained per cubic meter of concrete.

Cement content $=350 \mathrm{~kg} / \mathrm{m}^{3}$

Water content $=178.86 \mathrm{~kg} / \mathrm{m}^{3}$

Fine aggregate $=708.9 \mathrm{~kg} / \mathrm{m}^{3}$

Coarse aggregate $=1225.40 \mathrm{~kg} / \mathrm{m}^{3}$

Chemical admixture $=3.5 \mathrm{~kg} / \mathrm{m}^{3}$

Water cement ratio $=0.45$

\section{METHODOLOGY}

In the presnt experimental work, properties of materials used in the experimental work were determined. Then Flyash and GGBS based Geopolymer concrete (G40) cubes and conventional concrete (M40) cubes of size $150 \mathrm{~mm} \times 150 \mathrm{~mm} \times 150 \mathrm{~mm}$ were cast. 
It was found that sun dried Geopolymer concrete cubes attained target strength of the mix design when exposed under sun light for a period of 14 days where as conventional concrete cubes has to be cured for a period of 27 days by immersion in water. After completion of curing process, weight of both Conventional and geopolymer concrete cubes were taken. Later, both GPC and conventional concrete specimens were immersed in $5 \%$ of acidic solutions $\left(\mathrm{H}_{2} \mathrm{SO}_{4}, \mathrm{MgSO}_{4}\right)$ for a period of 7, 14, 28 days. The $5 \%$ acidic solutions containing $\mathrm{H}_{2} \mathrm{SO}_{4}$ and $\mathrm{MgSO}_{4}$ were prepared separately. After completion of immersion period, concrete specimens were taken out and allowed for drying for a period of 2 hours and weight of concrete cubes were determined. And also, the compressive strength of concrete cubes after acid immersion was determined and the obtained results are compared

\section{TEST RESULTS}

The compressive strength test on Geopolymer concrete and conventional concrete was performed using concrete cubes of 150x150x150 mm. Average of three specimens for the same configuration were considered. The curing media was replaced with fresh solution at the end of every week to maintain the same concentration (5\%) throughout the exposure period.

\subsection{Compressive Strength}

Chart 1 shows compressive strength of both GPC and conventional concrete (CC) before immersion in acidic solutions. Geopolymer concrete after 14 days of curing was $44 \mathrm{MPa}$ and Compressive strength of Conventional concrete after 27 days of curing was $40.88 \mathrm{MPa}$. 12M geopolymer concrete has higher compressive strength when compare to conventional concrete.

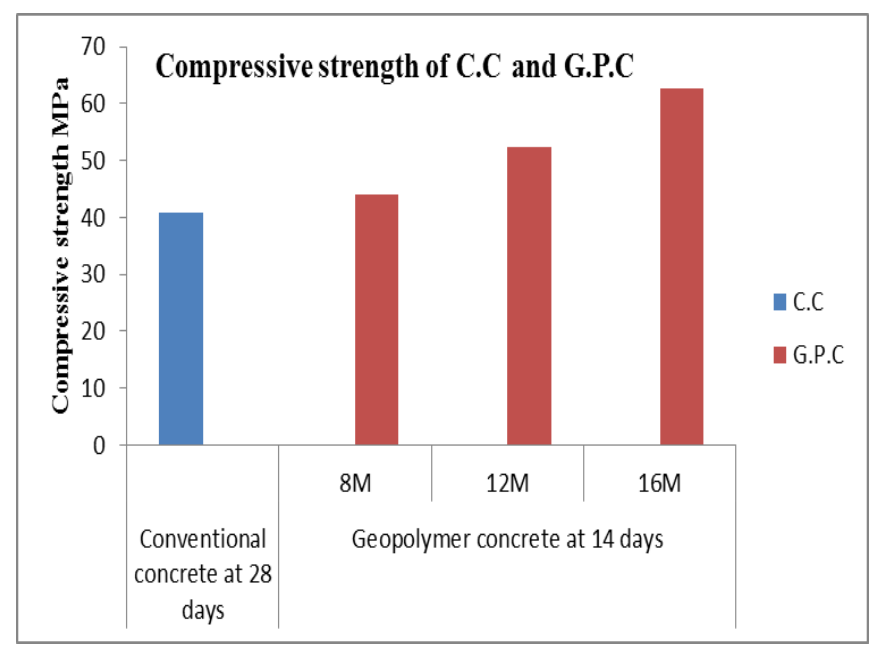

Chart 1: Compressive Strength of C.C and G.P.C before Acid Immersion

Table 2, Table3 and Table 4 shows summarized values of compressive strength of both GPC and CC after their immersion in 5\% acidic $\mathrm{H}_{2} \mathrm{SO}_{4}$ and $\mathrm{MgSO}_{4}$ solutions for a period of 7,14 and 27 days. Chart 2, Chart 3 and Chart 4 shows comparative variation of compressive strength of both CC and GPC with various periods of immersion in acidic solutions. It was observed that maximum reduction in strength occurred for conventional concrete cubes immersed in $5 \% \mathrm{H}_{2} \mathrm{SO}_{4}$ acidic solutions at all curing periods. Substantial reduction also occurred for $\mathrm{CC}$ cubes immersed in $5 \% \mathrm{MgSO}_{4}$ solutions when compared with GPC cubes.

Table 2: Residual Compressive Strength at 7 Days after Acid Immersion

\begin{tabular}{|c|c|c|c|}
\hline $\begin{array}{l}\text { Sl. } \\
\text { No. }\end{array}$ & $\begin{array}{l}\text { Type of } \\
\text { Concrete }\end{array}$ & \multicolumn{2}{|c|}{$\begin{array}{l}\text { Compressive strength(MPa) } \\
\text { at } 7 \text { days immersion in }\end{array}$} \\
\hline & & $\mathrm{H}_{2} \mathrm{SO}_{4}$ & $\mathrm{MgSO}_{4}$ \\
\hline 1 & C.C & 26.22 & 40 \\
\hline 2 & G.P.C(8M) & 40.88 & 41.33 \\
\hline 3 & G.P.C(12M) & 49.77 & 50.22 \\
\hline 4 & G.P.C(16M) & 58.66 & 60 \\
\hline
\end{tabular}

Table 3: Residual compressive strength at 14 days after

\begin{tabular}{|c|c|c|c|}
\hline $\begin{array}{l}\text { Sl. } \\
\text { No. }\end{array}$ & $\begin{array}{l}\text { Type of } \\
\text { Concrete }\end{array}$ & \multicolumn{2}{|c|}{$\begin{array}{c}\text { Compressive strength(MPa) } \\
\text { at } 14 \text { days immersion in }\end{array}$} \\
\hline & & $\mathrm{H}_{2} \mathrm{SO}_{4}$ & $\mathrm{MgSO}_{4}$ \\
\hline 1 & C.C & 21.33 & 37.77 \\
\hline 2 & G.P.C(8M) & 37.77 & 39.55 \\
\hline 3 & G.P.C(12M) & 46.22 & 48.66 \\
\hline 4 & G.P.C(16M) & 55.11 & 58 \\
\hline
\end{tabular}

Table 4: Residual compressive strength at 28 days after

\begin{tabular}{|c|c|c|c|}
\hline $\begin{array}{l}\text { Sl. } \\
\text { No. }\end{array}$ & $\begin{array}{c}\text { Type of } \\
\text { Concrete }\end{array}$ & \multicolumn{2}{|c|}{$\begin{array}{l}\text { Compressive strength(MPa) } \\
\text { at } 28 \text { days immersion in }\end{array}$} \\
\hline & & $\mathrm{H}_{2} \mathrm{SO}_{4}$ & $\mathrm{MgSO}_{4}$ \\
\hline 1 & C.C & 16.33 & 34.55 \\
\hline 2 & G.P.C(8M) & 35.55 & 38.66 \\
\hline 3 & G.P.C (12M) & 44 & 47.55 \\
\hline 4 & G.P.C(16M) & 52.88 & 57.11 \\
\hline
\end{tabular}




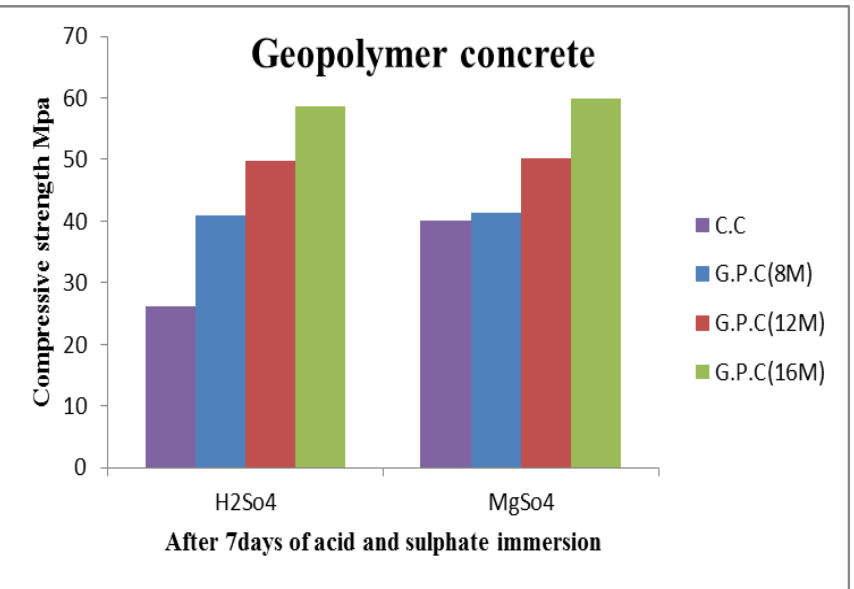

Chart 2: Compressive Strength of C.C and G.P.C after 7 Days Acid and Sulphate Immersion

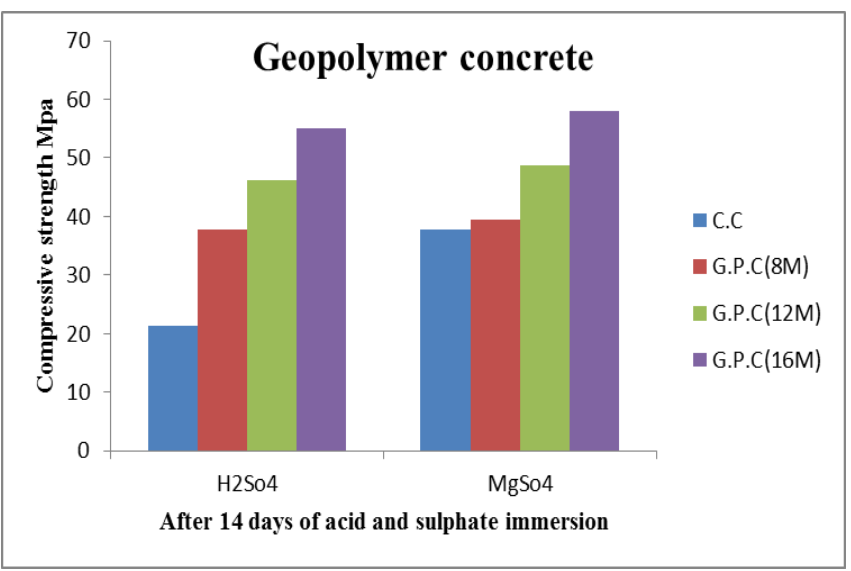

Chart 3: Compressive Strength of C.C and G.P.C after 14 Days Acid and Sulphate Immersion

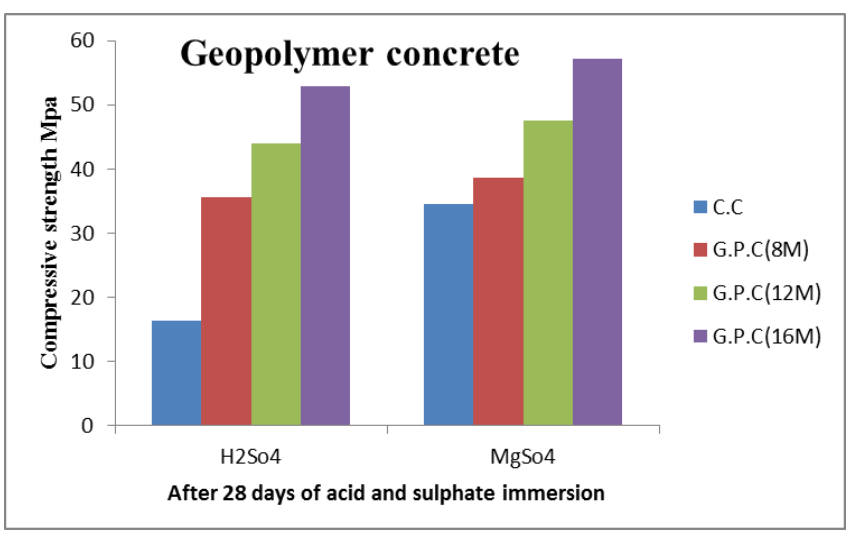

Chart 4: Compressive Strength of C.C and G.P.C after 28 Days Acid and Sulphate Immersion

\subsection{Mass Loss}

Chart 5 shows variation of mass of concrete cubes immersed in $5 \%$ acidic solutions containing $\mathrm{H}_{2} \mathrm{SO}_{4}$ and $\mathrm{MgSO} 4$ for various periods of immersion and compared with mass in $\mathrm{kgs}$ before immersion.. Conventional concrete showed more loss of mass when it is immersed in $\mathrm{H}_{2} \mathrm{SO}_{4}$ for a period of 27 days and loss of mass increases with increase in immersion period. Chart 6 and Chart 7 shows variation of mass of GPC cubes immersed in $5 \%$ acidic solutions containing $\mathrm{H}_{2} \mathrm{SO}_{4}$ and $\mathrm{MgSO} 4$ for various periods of immersion and compared with mass in $\mathrm{kgs}$ before immersion. Geopolymer concrete of $16 \mathrm{M}$ has higher durability properties in acid and sulphate immersion than conventional concrete and $8 \mathrm{M}, 12 \mathrm{M}$ geopolymer concrete as it shows less mass of loss upon immersion.

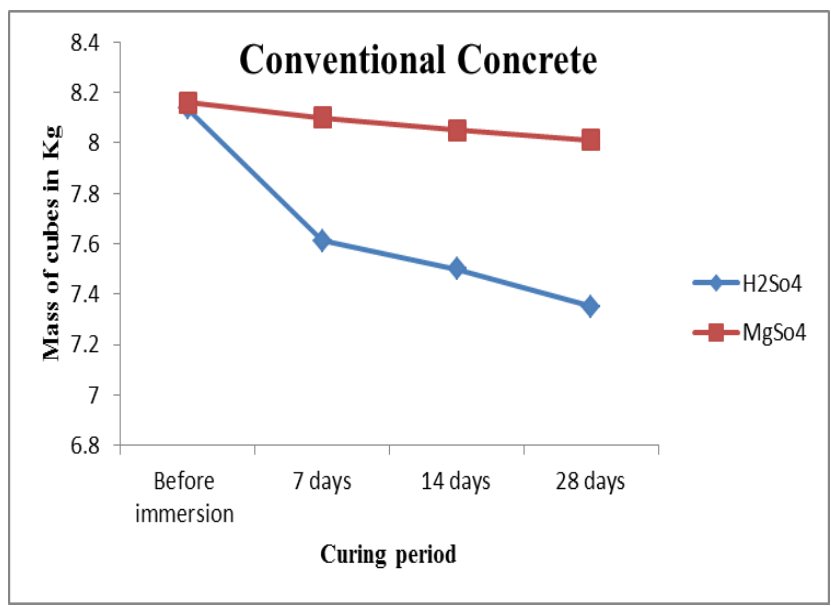

Chart 5: Loss of Mass of C.C Before and After Acid and Sulphate Immersion

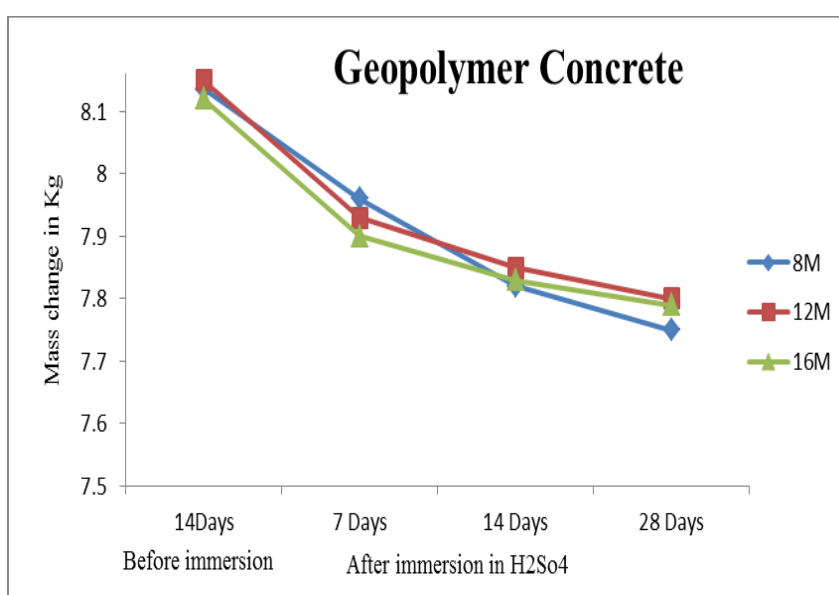

Chart 6: Loss of Mass of G.P.C Before and After Acid Immersion

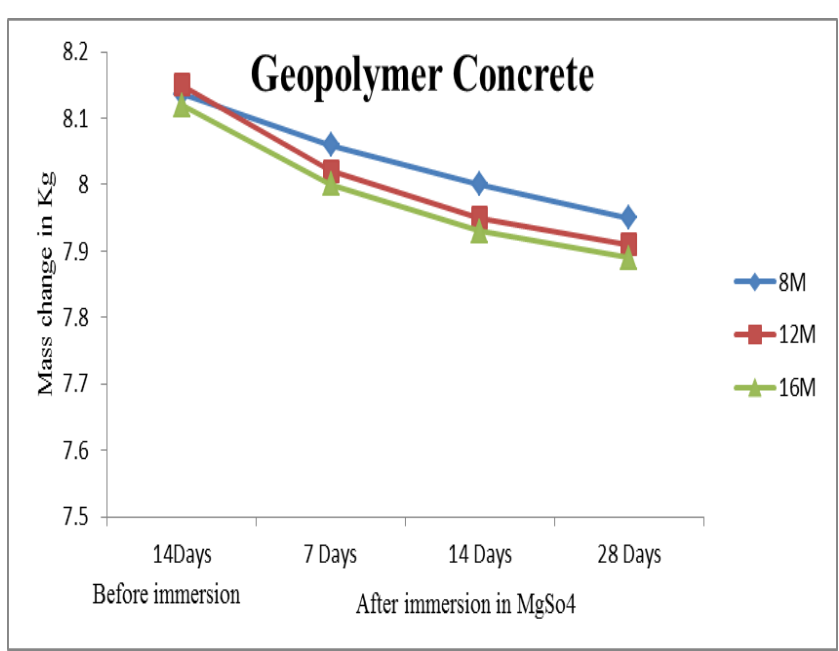

Chart 7: Loss of Mass of G.P.C Before and After Sulphate Immersion 


\section{CONCLUSION}

Based on present experimental investigation, the following conclusions are drawn:

- The GPC attains target compressive strength at much less curing period of 14 days under sun light curing when compared with conventional concrete which is to be cured for a minimum period of 27 days immersed in clean water.

- Both GPC and CC shows reduction in compressive strength upon immersion in 5\% acidic solutions containing $\mathrm{H}_{2} \mathrm{SO}_{4}$ and $\mathrm{MgSO} 4$. However, significant reduction in strength occurred for conventional concrete, indication better performance of GPC under acidic environment.

- $\quad$ Significant loss of mass are also indicated to occur for conventional concrete when compared to GPC. Hence it can be concluded that GPC is a better performance material in terms of acidic resistance when it is exposed to such conditions for a longer period.

\section{REFERENCES}

[1]. S.Kumaravel, K.Girija(1998), “Acid and salt resistance of geopolymer concrete with varying concentration of $\mathrm{NaOH}$ " Kumaravel, et al, Journal of Engineering Research and Studies

[2]. Antoni1, Oswyn K. Wattimena1,and Djwantoro Hardjito(2013), "Improving Surface Durability of High Volume Flyash Concrete with Application of Alkali Solution" Advanced Materials Research Vol. 626 (2013) pp 636-640 (2013

[3]. Mr. K. Madhan Gopal, Mr. B. Naga Kiran(2013), "Investigation on Behavior of Flyash Based Geopolymer Concrete in Acidic Environment" International Journal of Modern Engineering Research (IJMER) -Vol.3, Issue.1, Jan-Feb. 2013 pp-580-586

[4]. Ganapati Naidu.P, A.S.S.N.Prasad, S.Adiseshu, P.V.V.Satayanarayana (2012), "A Study on Strength Properties of Geopolymer Concrete with Addition of G.G.B.S" International Journal of Engineering Research and Development -Volume 2, Issue 4 (July 2012), PP. 1928

[5]. Madheswaran C. K, Gnanasundar G, Gopalakrishnan. N(2013)," Effect of molarity in geopolymer concrete" International Journal of Civil and Structural EngineeringVolume 4, No 2, 2013

[6]. Ammar Motorwala1, Vineet Shah, Ravishankar Kammula(2013), “Alkali activated Flyash Based Geopolymer Concrete" International Journal of Emerging Technology and Advanced Engineering - Volume 3, Issue 1, January 2013

[7]. Shankar H. Sanni1, Khadiranaikar, R. B(2012), "Performance of geopolymer concrete under severe environmental conditions" International Journal of Civil and Structural Engineering - Volume 3, No 2, 2012

[8]. IS 10262-2009: "Guidelines for concrete mix design

Proportioning "[CED 2: Cement and Concrete]

\section{BIOGRAPHIES}

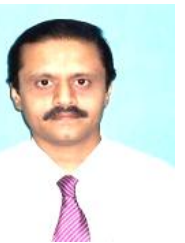

Dr.M.T. Prathap Kumar, Senior Professor, has 27 years of teaching experience. He has to his credit several papers in reputed national and international journals and conferences. He has presented many technical papers in USA, Japan, Indonesia and Singapore and has delivered invited lectures at University of Illinois, Chicago and many such lectures in India. He is a peer reviewer for many international journals

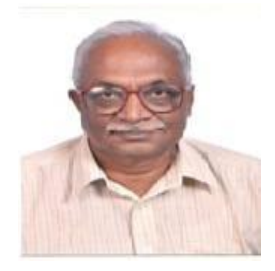

Dr. W.P.Prema Kumar, Senior Professor has 35 years of teaching experience. He has to his credit several papers in reputed national and international journals and conferences. $\mathrm{He}$ is a member of several University bodies, societies etc.

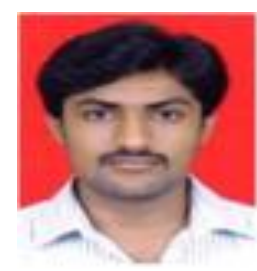

Srinivas K S is a PG student, doing his M.Tech in Structural Engineering of VTU, Belgaavi at Reva Institute of Technology and Management, Bengaluru. 